\title{
Thymic Small Cell Carcinoma
}

National Cancer Institute

\section{Source}

National Cancer Institute. Thymic Small Cell Carcinoma. NCI Thesaurus. Code C6460.

An aggressive, small cell, poorly differentiated thymic neuroendocrine carcinoma,

characterized by the presence of a high mitotic rate and numerous apoptotic bodies. 